\title{
Sequencing Analysis of $c v a C$ Gene in Acinetobacter Baumannii That Isolates from Different Infections
}

\author{
Rana M. Abdullah*, Rasha Z. T. Ahmed \\ Department of Biology, College of Education Ibn-Al Haitham, University of Baghdad - Iraq
}

\section{Article information}

\section{Article history:}

Received: June, 07, 2021

Accepted: July, 25, 2021

Available online: December, 04, 2021

Keywords:

Colicin,

Genotypic analysis,

Mutations

*Corresponding Author:

Rana M. Abdullah

dr.rana_alshwaikh@yahoo.com

\begin{abstract}
Acinetobacter baumannii is one of the opportunistic nurses responsible for many acquired infections in hospitals due to its ability to resist many antibiotics. This is one of the problems facing hospitals in the world. Identification of the $c v a C$ gene and sequence analysis in Acinetobacter baumannii isolates from various infections, and mutation detection in this gene. From $1^{\text {st }}$ of September to $30^{\text {th }}$ of November, 2016, 200 Acinetobacter baumannii isolates were obtained from various clinical samples. Follow fifty isolates from blood, twenty isolates from urinary tract infections, thirty isolates from wound infections, forty isolates from burn infections and twenty-five isolates from stool samples from various hospitals (Central Children's Hospital, Al Karama Hospital, Karkh General Hospital, Al-Ameen Medical City Hospital, Educational Labs, Baghdad Teaching Hospital, Child Protection Hospital, Burns and Wounds Hospital) in Baghdad city. Identification forty isolates confirmed that they belong to Acinetobacter baumannii, including fourteen isolates from a stool sample, nine isolates from blood, eight isolates from burns, four isolates from wound infections, and Respiratory tract infection, , and only one isolate from urinary tract infections sample. Genotypic detection of the cvaC gene of Acinetobacter baumannii showed the presence of this gene in 16 isolates (40\%) and Sequencing analysis of $c v a C$ has shown seven genetic mutations and only one mutation has been converted amino acid Alanine to Valine. The amino acid Alanine was changed to Valine in Position 656 at Subject 678, resulting in silent mutations that did not affect protein translation and other mutations that resulted in a change in the amino acid arrangement and protein translation.
\end{abstract}




\section{Introduction}

Acinetobacter baumannii is a Gram-negative, non-motile, strict aerobic, non-fermented lactose, coccobcilli, catalase-positive, and oxidase-negative [1,2]. Acinetobacter baumannii is found in nature and has been isolated from various environmental sources, including soil, water, sewage, the surfaces of living things, and medical settings. It is known for its capacity to build biological membranes [3,4]. These opportunistic bacterial pathogens cause many opportunistic infections in hospitals, including pneumonia, burns infection, wound infection, septicemia, endocarditis, and urinary tract infection.

Many of the virulence characteristics that help bacteria because disease is present in these bacteria, including capsules, biofilm development, loads the bacteria that benefit the biofilm, and protects the creature from unusual natural pressure, such as anti-infection chemicals and cleansers [5] and the production of enzymes such as lipase and protease [6,7]. A. baumannii is one of the opportunistic nurses responsible for many acquired infections in hospitals due to its ability to resist many antibiotics. This is one of the problems facing hospitals in the world and comes after Pseudomonas aeruginosa was isolated from hospital environments $[8,9,10,11]$.

Colicin is a protein produced by most Escherichia coli strains that affect bacteria closely related to E. coli. Colicin is found in members of the Enterobacteraceae family, including Shigella and Citrobacter [12]. Colicin is divided into several types A, B, D, V, and I [13]. Colicin V is a peptide antibiotic produced by members of the Enterobacteraceae family and A. baumannii that kills bacteria of other species. Colicin is encoded by four genes: $c v a A, c v a B, c v a C, c v a I$, and cvaC. Colicin, which is made up of 103 amino acids, is produced by these genes. Colicin $\mathrm{V}$ is a bactericidal that kills sensitive cells by altering membrane potential [14].

The mechanism of action depends on the presence of specific receptors present in or on cells sensitive to Colicin. There are different varieties of Colicin; for examples Marscin, or the term Proteuocin if Colicin is produced from Proteus spp. [15, 16, and 17].

This study aimed to detect the cvaC gene and sequences analysis of the cvaC gene in $A$. baumannii and detect the mutations in this gene and their effect on protein synthesis.

\section{Experimental details}

\section{1: Collection of samples and identification of bacterial isolates}

A. baumannii isolates (200) were collected from different clinical samples (blood, stool, wounds, burns, and urinary tract infections) from several hospitals in Baghdad (Central Children's Hospital, Al Karama Hospital, Karkh General Hospital, Al-Ameen Medical City Hospital, Educational Labs, Baghdad Teaching Hospital, Child Protection Hospital and burns and Wounds Hospital) during the period from $1^{\text {st }}$ Sep. to $30^{\text {th }}$ Oct.2016 The samples were cultured separately on MacConkey agar and blood agar then identified by using biochemical tests including oxidase and catalase tests. Conformation of identification was done by using the API20E system and VITEK-2 system [16].

\section{2: Extraction of DNA}

According to the manufacturer's instructions, DNA from bacterial isolates was extracted using a DNA kit (Geneaid Biotech kit system, UK).

\section{3: Preparation of $c v a C$ primers}

The stock solution of primers was prepared according to the instructions of the manufacturer (Alpha DNA Canada) mentioned in Table (1) using sterile distilled deionized water to obtain a concentration of $100 \mathrm{pmol} / \mu \mathrm{l}$. The solution of each initiator was present separately at 10 $\mathrm{pmol} / \mu \mathrm{l}$ by adding $10 \mu \mathrm{l}$ from each stock solution to $90 \mu \mathrm{l}$ of D.W. and mixed well with Vortex mixture, keeping with stock solutions at $20^{\circ} \mathrm{C}$ and mixing the initiator solution after removing it from ice using the Vortex carburetor prior to use. 
Table (1): Nucleotide sequence of the primer used for detection $c v a C$ gene.

\begin{tabular}{|c|c|c|c|c|}
\hline \multicolumn{2}{|c|}{ Genes } & $\begin{array}{c}\text { Sequencing } \\
\text { Primer sequence }\left(5^{\prime} \_3^{\prime}\right)\end{array}$ & $\begin{array}{l}\text { Product size } \\
\text { (bp) }\end{array}$ & Sours \\
\hline \multirow{2}{*}{$c v a C$} & $\mathrm{~F}$ & CACACACAAACGGGAGCTGTT & \multirow{2}{*}{680} & \multirow{2}{*}{ [18] } \\
\hline & $\mathrm{R}$ & CTTCCCGCAGCATAQTTCCAT & & \\
\hline
\end{tabular}

The PCR polymerase reaction mixture for $\boldsymbol{c v a C}$ gene was prepared as shown in Table 2 .

Table (2) PCR mixture of $c v a C$ gene.

\begin{tabular}{|c|l|c|}
\hline No. & PCR mixture & Volume $(\boldsymbol{\mu l})$ \\
\hline $\mathbf{1}$ & F-primer & 1 \\
\hline $\mathbf{2}$ & R-primer & 1 \\
\hline $\mathbf{3}$ & Template DNA & 2 \\
\hline $\mathbf{4}$ & Nuclease Deionized nuclease-free water & 6 \\
\hline $\mathbf{5}$ & GO Taq green master mix & 10 \\
\hline \multicolumn{2}{|c|}{ Total } & 20 \\
\hline
\end{tabular}

The contents of the PCR tubes were mixed well using the Vortex then placed in a PCR thermal cycler, as shown in Table (3).

Table (3): Optimal conditions of PCR reaction for determination of $c v a C$ gene.

\begin{tabular}{|c|l|l|}
\hline Step & Program \\
\hline $\mathbf{1}$ & \multicolumn{1}{|c|}{ Only one cycle for 5 minutes at a temperature of $94{ }^{\circ} \mathrm{C}$ for the primary DNA denaturation. } \\
\hline 2 & 30 cycles included: \\
\cline { 2 - 3 } & A & 50 sec at $9{ }^{\circ} \mathrm{C}$ for DNA template denaturation. \\
\cline { 2 - 3 } & B & $45 \mathrm{sec}$ at $55^{\circ} \mathrm{C}$ for the primers to bind to DNA template annealing at $58{ }^{\circ} \mathrm{C}$ for $60 \mathrm{sec}$. \\
\cline { 2 - 3 } & $\mathrm{C}$ & $45 \mathrm{sec}$ at $72^{\circ} \mathrm{C}$ for the associated primers to be elongated. \\
\hline $\mathbf{3}$ & Only one cycle for 8 minute at $72{ }^{\circ} \mathrm{C}$ for the final elongation of the double DNA strip. \\
\hline
\end{tabular}

\section{4: Electrophoresis of PCR products}

The PCR products $(5 \mu 1)$ were electrophorized on $2 \%$ agarose gel with $5 \mu 1$ Ethidium bromide, at 100 vol. for $80 \mathrm{~min}$. The DNA bands were visualized and photographed under UV light [19].

\section{Results and discussion}

\section{1: Identification}

Fourteen isolates from stool, nine isolates from blood, eight isolates from burns, four isolates from wound infections and respiratory tract infections, and only one strain from urinary tract infections were identified as Acinetobacter baumannii.

\section{2: Genotypic detection}

Acinetobacter baumannii cvaC gene genotyping revealed that 16 isolates (40\%) were Acinetobacter baumannii and had $c v a C$ genes with a molecular weight of $680 \mathrm{bp}$. Figure (1). This result was consistent with a study by [17], which discovered that 17 isolates (34\%) carried the $\mathrm{cvaC}$ gene. In addition, ColicinV, a peptide antibiotic that inhibits bacteria by disrupting the cell membrane and becomes a bacterium killer when it enters the inner membrane of bacteria during perplasma membranes, was formed by the $c v a C$ gene $[14,20]$. 

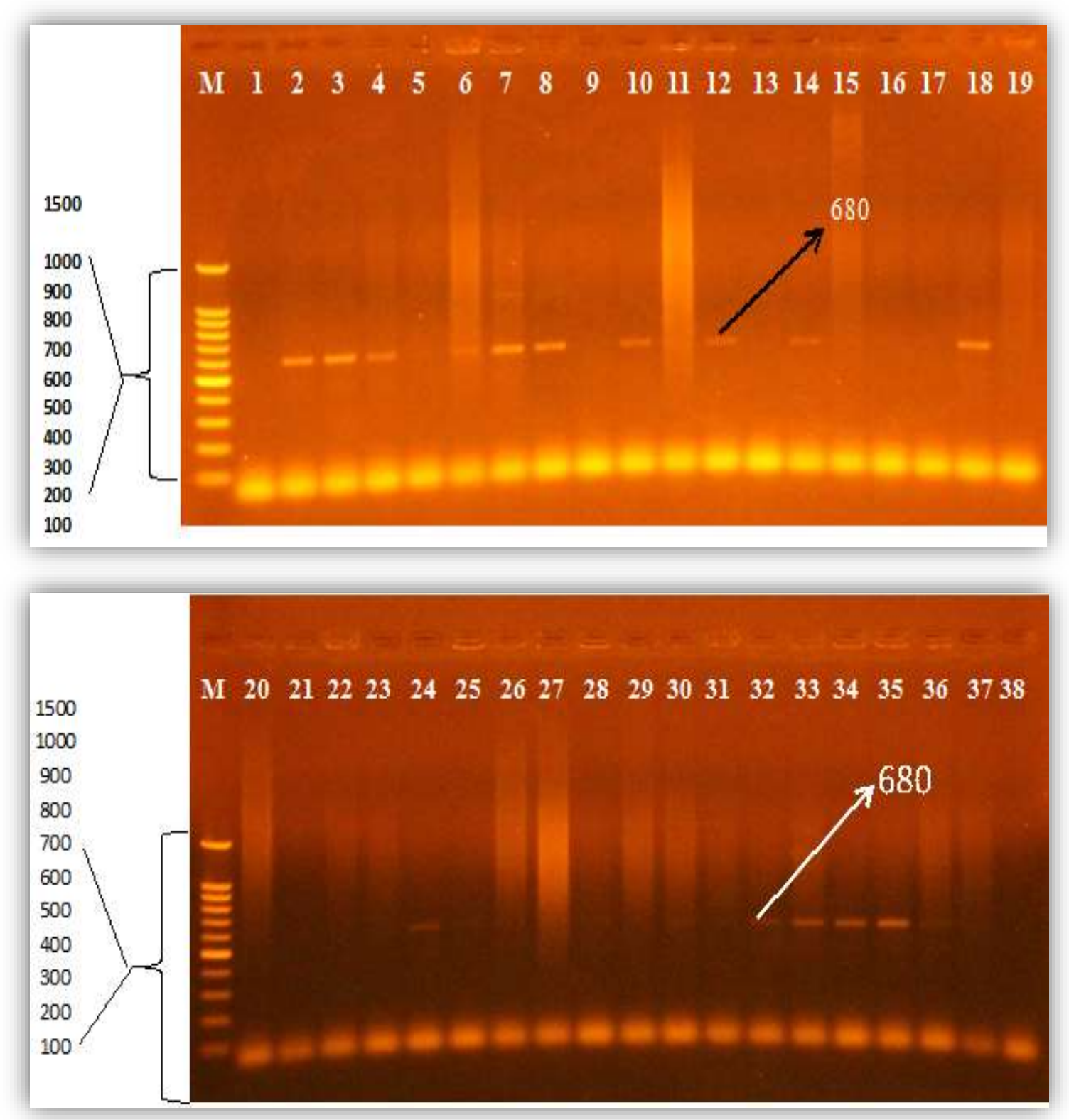

Figure 1: Electrophoresis of PCR product for detection cva C gene (680 bp) in A. baumanniii isolates on $2 \%$ agarose and 100 volts for $80 \mathrm{~min}$. The M ladder (100-1500 bp); the 2, 3, 4, 6, 7, $8,10,12,14,18,24,32,33,34,35$ and 36 were positive isolates.

\section{3: Sequences analysis}

Sequences analysis of $c v a C$ gene in A. baumannii isolates (A7 isolate from stool and A12 isolate from blood samples) were done. The results showed that there are seven genetic mutations include: Mutations in Position 231 at Subject 523, in Position 231 at Subject 254, in position 266 at subject 288, in Position 453 at Subject 490, in Position 510 at Subject 547, in Position 596 at Subject 618, in Position 656 at Subject 678.

The changes in Nitrogen bases of their mutation were showed that Guanine replaced thymine at Position 231 at Subject 253 and each Thymine was replaced by Cytosine in different positions and subjects included (Position 232 at Subject 254, Position of 266 at Subject 288, Position 453 at Subject 490 and Position 510 at Subject 547 respectively). While Thymine was replaced with Adenine at Position 596 at Subject 618. Whereas Cytosine was replaced with Thymine at 
Position 656 at Subject 678 all the results as shown in Table (4) and figure (2).

Analyzing the mutations' translation results revealed that there were silent mutations that had no effect on amino acid translation in all six mutations. In contrast results revealed that only one mutation changed amino acid translation, changing the amino acid Alanine to the amino acid Valine in position 656 at subject 678. Missense mutations are mutations that result in a change in amino acid in the resultant protein sequence. [21].The change in the sequence of amino acids was due to the loading of another amino acid instead of the original amino acid. The effect of a missense mutation on the resulting protein is determined by the location of the amino acid that has been changed, as follows: Acceptable, partially acceptable, or unacceptable [22].

Table (4): Changes in nitrogen bases and their effect on amino acid translation in the Gene cva C from A. baumanniiii isolates A7 and A 12.

\begin{tabular}{|c|c|c|c|c|c|c|}
\hline No. & Nitrogen bases & $\begin{array}{c}\text { Changes in } \\
\text { Nitrogen bases }\end{array}$ & Position & Subject & $\begin{array}{c}\text { Amino } \\
\text { acid }\end{array}$ & $\begin{array}{c}\text { Changes in } \\
\text { amino acid }\end{array}$ \\
\hline $\mathbf{1}$ & Thymine & Guanine & $\mathbf{2 3 1}$ & $\mathbf{2 5 3}$ & - & - \\
\hline $\mathbf{2}$ & Thymine & Cytisine & $\mathbf{2 3 1}$ & $\mathbf{2 5 4}$ & - & - \\
\hline $\mathbf{3}$ & Thymine & Cytisine & $\mathbf{2 6 6}$ & $\mathbf{2 8 8}$ & - & - \\
\hline $\mathbf{4}$ & Thymine & Cytisine & $\mathbf{4 5 3}$ & $\mathbf{4 9 0}$ & - & - \\
\hline $\mathbf{5}$ & Thymine & Cytisine & $\mathbf{5 1 0}$ & $\mathbf{5 4 7}$ & - & - \\
\hline $\mathbf{6}$ & Thymine & Adenine & $\mathbf{5 9 6}$ & $\mathbf{6 1 8}$ & - & - \\
\hline $\mathbf{7}$ & Cytosine & Thymine & $\mathbf{6 5 6}$ & $\mathbf{6 7 8}$ & Alanine & Valine \\
\hline
\end{tabular}




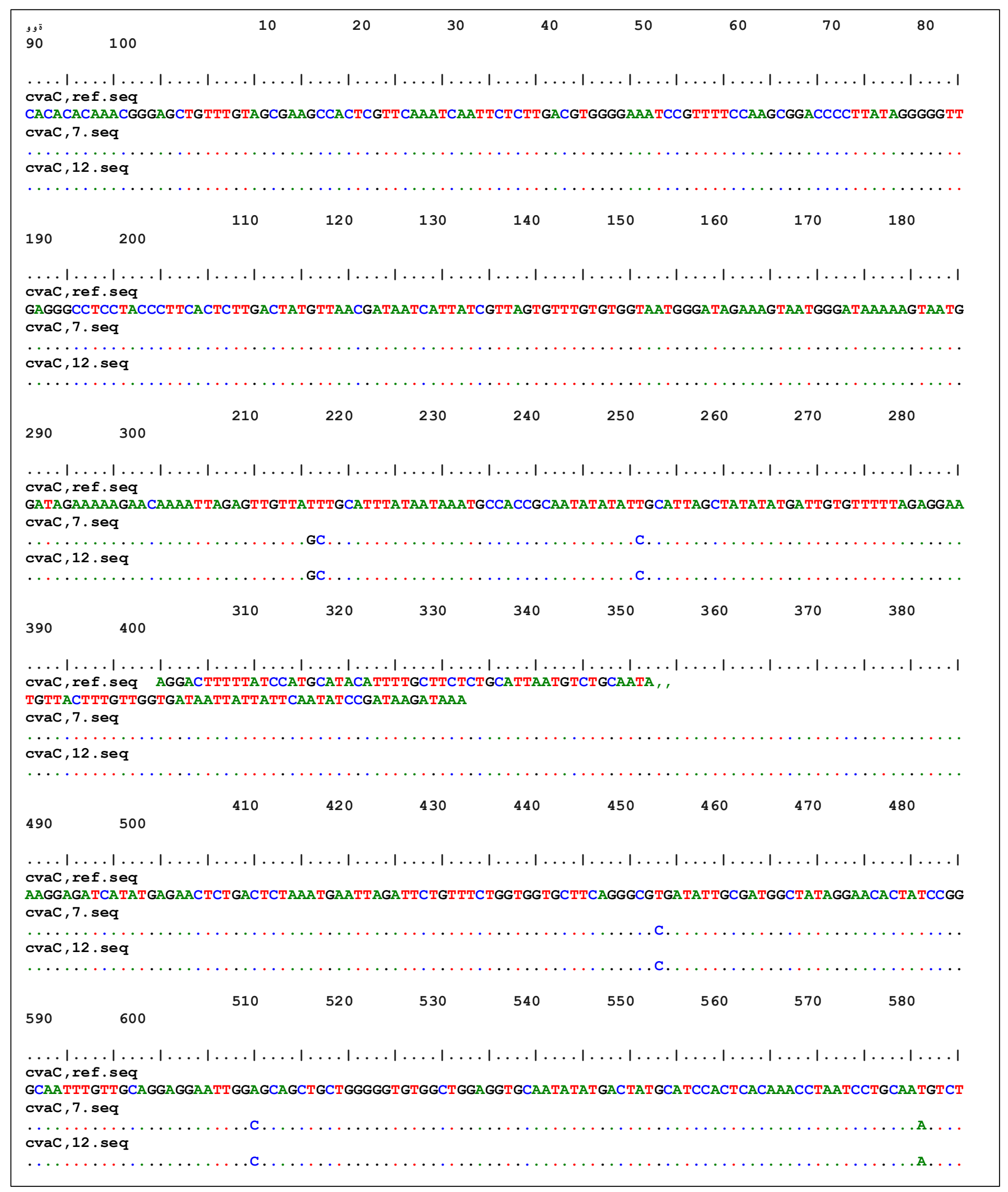

Figure 2: Analysis of the multiple sequences of the reference $c v a C$ gene with two changes in $A$. baumanii isolates A7 and A12 using the BioEdit Sequence Alignment Editor Software. 


\section{Conclusions}

Sequencing analysis results of $c v a C$ gene showed silent mutations that did not affect protein translation, and only one mutation that led to change in the amino acid Alanine was converted Valine in Position 656 at Subject 678.

Conflict of Interest: The authors declare that they have no conflict of interest.

\section{References}

[1] H. Momtaz, S. Seifati, M. Tavakol, "Determining the Prevalence and Detection of the Most Prevalent Virulence Genes in Acinetobacter Baumannii Isolated from Hospital Infections", International Journal of Medical Laboratory. Vol. 2, No.2, p. 87-97, 2015.

[2] H. Singh, P. Thangaraj, A. Chakrabarti, "Acinetobacter baumannii: A Brief Account of Mechanisms of Multidrug Resistance and Current and Future Therapeutic Management", Journal of Clinical and Diagnostic Research, vol. 7, no.11, p. 2602-2605, 2013.

[3] A. A. Mahdi, R. M. Abdullah, "Molecular study of Carbapenime resistant genes in Acinetobacter baumannii that isolated from different clinical cases", Biochemical and Cellular Archives, vol. 20, no. 1, p. 1605-1610, 2020.

[4] G. M. Elipoulose, L.L. Maragakis, T.M. Perl, "Acinetobacter baumannii: epidemiology, antimicrobial resistance, and treatment options", Clinical Infect Disease. Vol. 46, no. 8, p. 1254-1263, 2008.

[5] N. N. Hussein and M. M. Khadum, " Evaluation of the Biosynthesized Silver Nanoparticles" Effects on Biofilm Formation", Journal of Applied Sciences and Nanotechnology, Vol.1, No. 1, 2021

[6] A. A. Mahdi, R. M. Abdullah, "Detection of some antibiotic resistance genes and their gene expression In Acinetobacter baumannii isolated from different clinical cases" Master Thesis, College of Education for pure science, University of Baghdad, 2019.

[7] H.J. Doughari, P.A. Ndakidemi, I.S. Human, S. Benade, "The ecology, biology and pathogenesis of Acinetobacter spp.: an overview: Microbes and environments", Journal of Simulation and Mechanical Engineering. Vol. 26, no. 2, p. 101-112, 2011.

[8] A. Kilic, H. Li, A. Mellmann, A.C. Basustaoglu, M. Kul, Z. Senses, H. Aydogan, C.W. Stratton, D. Harmsen, Y.W. Tang, " Acinetobacter septicus sp. nov. Association with a nosocomial outbreak of bacteremia in a neonatal intensive care unit. Journal of Clinical Microbiology", vol. 46, no. 3, p. 902-908, 2008.

[9] C. Luísa, S. Antunes, V. Paolo, J.T. Kevin, " Acinetobacter baumannii: evolution of a global pathogen", Pathogens and Disease of Journal. Vol. 71, no. 3, p. 292-301, 2014.

[10] A. Y. Peleg, H. Seifert, D.L. Paterson, "Acinetobacter Pellicle polysaccharide formation", Journal of Bioscience and Bioengineering. Vol. 74, no. 8, p. 1591-1597, 2008.

[11] B. H. Jasim and E. H. Ali. Enhanced Production of Fibrinolytic Enzyme from Pseudomonas aeruginosaby Optimization Media Components. Journal of Applied Sciences and Nanotechnology, Vol. 1, No. 2, 2021.

[12] A. Gratia, P. Fredericq," Diversite des souches antibiotiques Bacterium coli", eteten due variable de leur champ d'action. C. R. Soc. Biol., vol. 140, p. 1032-1033, 1946.

[13] L. Gilson, H.K. Mahanty, R. Kolter, "Genetic analysis of MDR-like export system: the secretion of colicin V.", Journal of European Molecular Biology Organization. Vol. 9, pp. 3875-3894, 1990.

[14] F. Gerard, N, Pradel, L. Wu," Bactericidal Activity of Colicin V Is Mediated by an Inner Membrane Protein, Sda, C. of Escherichia coli", Journal of Bacteriology. Vol. 187, no. 6, 1945-1950, 2005.

[15] M. S. Mustafa,. "Molecular Study of Multidrug Resistant Klebsiella pneumoniae isolated from different clinical samples", Master Thesis, College of Education for pure science, University of Baghdad. pp. 3-21, 2018.

[16] M. Darvishi,"Virulence factor Profile and Antimicrobial Resistance of Acinetobacter baumannii Strain isolated from various infection Recovered from immune suppressive patients", Bio medical Pharmacology Journal. vol. 9, no. 3, p. 1057-10623, 2016.

[17] P. Mohajeri, S. Sharbati, A. Farahani, Z. Rezaei, (2016),"Evaluate the frequency 
distribution of non-adhesive virulence factors in carbapenemase-producing Acinetobacter baumannii isolated from clinical samples in Kermanshah", Journal of Natural Science Biology and Medicine. Vol. 7, no. 1, p. 58-61, 2016.

[18] J.R. Johnson, A. L. Stell, "Extended virulence genotypes of Escherichia coli strains from patients with sepsis in relation to phylogenic and host compromise", Journal of Infection Diseases. Vol. 181, p. 261-272, 2000.

[19] J. Sambrook, D.W. Rusell, "Molecular cloning a laboratory manual", Cold spring Harbor Laboratory press. New York. U.S., 2001.

[20] R. Daryanavard, H. S. Safaei,"Virulence genes and antimicrobial resistance properties of Acinetobacter baumannii isolated from pediatrics suffered from UTIs', International Journal of Advanced Research in Biological Sciences, vol. 2, no. 11, p. 272-279, 2015.

[21] R. M. Abdullah and R. Z. T. Ahmed, "Molecular Study of the cnf1 and cnf2 (Cytotoxic Necrotizing Factors) Genes of Acinetobacter baumannii Isolated from Different Diseases" Diyala Journal for Pure Science, Vol. 17, Issue: 1, 2021.

[22] Z. M. Khafaji, " Microbial Biotechnology (Molecular Trends)", $1^{\text {st }}$ ed., The Republic of Iraq, Ministry of Higher Education and Scientific Research, Baghdad University, Institute of Genetic Engineering and Biotechnology, Postgraduate Studies, 2008. 